\title{
Understanding Reference: Morphological Marking in JAPANeSe
}

\author{
Shinichi SHOJI \\ Organization for the Development of Higher Education \\ and Regional Human Resources, \\ Mie University, Japan
}

\begin{abstract}
This study investigates reference resolution with repeated-name anaphors in Japanese, particularly focusing on (i) subject anaphor with the nominative postposition ga, (ii) topic-subject anaphor with the topic postposition wa, (iii) scrambled object anaphor with the accusative postposition $o$, and (iv) topicobject anaphor with the topic postposition wa. A self-paced sentence-by-sentence reading experiment was conducted using two-sentence discourse items followed by comprehension questions, aiming to examine which type of anaphor would trigger a faster realization of the anaphor-antecedent relationship. The discourse items included antecedents in the first sentence and anaphors in the second sentences, and the comprehension questions asked about the antecedents in the first sentences. Results showed that the comprehension questions for the discourses that included topic anaphors (topic-subject-wa and topic-object-wa) were responded to faster than those for the discourses that included non-topic anaphors (subject-ga and scrambled object-o). The results indicate that anaphors' topic-hood given by wa facilitates the realization of antecedents.
\end{abstract}

Keywords: reference; subject; object; topic; scrambling

\section{Povzetek}

V študiji o referenčni ločljivosti naveznikov (anafor) s ponavljajočimi se imeni $v$ japonščini se avtor posveča naslednjim štirim točkam: (i) osebkovemu navezniku z imenovalniškim členkom ga, (ii) tematskemu osebkovemu navezniku s tematskim členkom wa, (iii) mešanemu predmetnemu navezniku $v$ premeni in $s$ tožilniškim členkom $o$ ter (iv) tematskemu predmetnemu navezniku $s$ tematskim členkom wa. $\mathrm{V}$ bralnem eksperimentu, $\mathrm{v}$ katerem je bralec samonadzoroval hitrost branja posameznih stavkov, je bil uporabljen dvostavčni diskurz. Temu je sledilo vprašanje, preko katerega je avtor ugotavljal, kateri tip naveznika sproža najhitrejšo navezavo med naveznikom in nanašalnico. Nanašalnice so bile vedno vključene $v$ prvi in navezniki v drugi stavek, vprašanja so iskala informacije iz prvega stavka, tj. o nanašalnicah. Rezultati so pokazali, da je bila odzivnost na vprašanja hitrejša v primerih tematskih naveznikov (tematskemu osebkovemu navezniku s tematskim členkom wa in tematskemu predmetnemu navezniku s tematskim členkom wa) kot netematskih (osebkovemu navezniku $\mathrm{z}$ imenovalniškim členkom $g a$ in mešanemu predmetnemu navezniku $\mathrm{v}$ premeni in $\mathrm{s}$ tožilniškim členkom o), zaradi česar lahko sklepamo, da tematičnost, ki jo definira tematski členek wa, omogoča realizacijo nanašalnice.

Ključne besede: referenca; osebek; predmet; tema; skladenjske premene

Acta Linguistica Asiatica, 7(1), 2017.

ISSN: 2232-3317, http://revije.ff.uni-lj.si/ala/

DOI: 10.4312/ala.7.1.9-21 


\section{Introduction}

Reference resolution has been widely discussed in the field of psycholinguistics, concerning the forms of anaphors. It is well known that anaphors in pronoun forms are preferred to those in repeated-name forms when antecedents are prominent, namely, when they are grammatical subjects or first mentioned entities in a sentence (Ariel, 1990; Gundel, Hedberg, \& Zacharski, 1993; Gordon, Grosz \& Gillian, 1993; among others). According to Gordon and Hendrick (1998, p. 390, 393, 416), in English, pronouns are immediately interpreted as anaphors, which leads readers to looking for their referents, whereas repeated-name anaphors tend not to be initially interpreted as anaphors. Readers of a repeated-name anaphor first establish a general concept of the entity indicated by the repeated name, and later realize the referential relationship between the entity and its referent, resulting in a slower identification of the referents. This relatively slower realization of antecedents is reflected in slower processing times for sentences with repeated-name anaphors compared with sentences with pronoun anaphors where the anaphors are both grammatical subjects (Gordon, Grosz \& Gilliom, 1993, among others), e.g., 'Harry is a member of a track team. Harry/He recruited Fred for the team because he is the fastest runner in the school.'.

In Japanese, repeated-name anaphors can appear in several variations. One is grammatical subject anaphors marked with the nominative postposition ga (e.g., HARRY-GA Fred-o sasotta 'Harry recruited Fred'), which would be the most equivalent to the repeated-name anaphors in other languages that elicited slower processing in early studies. However, instead of ga, grammatical subjects can be marked with the topic postposition wa (e.g., HARRY-WA Fred-o sasotta 'Harry recruited Fred'), which explicitly shows that the grammatical subjects are discourse topics (i.e., topic-subject). ${ }^{1}$ In addition, in scrambled sentences, non-subjects such as grammatical objects with the accusative postposition $o$ can be positioned at the beginning of a sentence, similar to a subject's position (e.g., HARRY-O Fred-ga sasotta 'Fred recruited Harry). Moreover, the scrambled/fronted non-subject can be a topic (e.g., HARRY-WA Fred-ga sasotta 'Fred recruited Harry'). The present study investigated the processing of these different types of sentence-initial repeated-name anaphors in Japanese, aiming to examine whether any particular types of repeated-name anaphors would trigger a faster realization of their referents. For non-subjects, this study used grammatical objects, and thus the following four variations of repeated-name anaphors were tested: (nontopic) subject-ga, topic-subject-wa, (non-topic) scrambled object-o, and topic-objectwa.

\footnotetext{
${ }^{1}$ The term topic-subject is sometimes called topicalized subject in linguistic articles. However, in the author's view, topics are base-generated, and they are not moved from the grammatical subject position. Thus, the term topicalized is not used in this article.
} 


\section{Topic and Scrambling}

It is widely acknowledged that a topic refers to information that has been presented earlier (Chafe, 1987; Kuno, 1973, p. 38, among others). Prince (1978) states that a speaker marks an entity as a topic when the listener already recognizes the entity. In response, the entity marked as the topic leads the listener to search for its antecedent in the preceding context, the ongoing situation, or the listener's long-term memory (Haviland \& Clark, 1974, p. 512, 513). This process seems similar to that for English pronouns, where Gordon and Hendrick $(1998$, p. 390, 393, 416) argue that pronouns are immediately interpreted as anaphors and readers look for antecedents. In short, a topic is essentially anaphoric, as Halliday (1967, p. 199) argues: a topic is concerned with the relation of what is currently being said to what was said earlier in the discourse. According to the above arguments, in Japanese, topic anaphors with the topic postposition wa should be more quickly interpreted as anaphors and to trigger antecedent-realization compared with non-topic anaphors (with ga, o, etc.), which would be reflected in different processing times, even if the anaphors are all repeatedname anaphors. This prediction is summarized below.

(1) topic-subject-wa, topic-object-wa $<$ (faster to process than) subject-ga, scrambled object-o

However, a possible problem of processing a sentence with topic-wa is that the topic postposition wa by itself does not tell its grammatical role, such as topic-subject or topic-object. In fact, topic-wa anaphors in Japanese are much more frequently topicsubjects than other types of topics (Martin, 1975; Nishimura, 1989, p. 374). Due to this frequency difference, any type of topic-wa might be initially interpreted as a topicsubject. This possibility is further supported by the fact that any topic-wa tends to be positioned at the beginning of a sentence, which is similar to the grammatical subject position. Therefore, readers of a topic-object (or any non-subject topics) would have to reanalyze it after they initially misinterpret it as a topic-subject. Accordingly, sentences with topic-objects could be processed more slowly than sentences with topic-subjects, as summarized below.

(2) topic-subject-wa $<$ topic-object-wa

Note that this above prediction is not related to the realization of the anaphorantecedent relationship. Rather, this is an issue of realizing the grammatical role of a topic within a sentence, i.e. topic-subjects and topic-objects do not have to be anaphors to elicit this processing-time difference.

Another sentence-level issue is word order. In Japanese, the default word order of the argument nouns and a verb is 'subject - object - verb (SOV)'. Therefore, a scrambled word order such as OSV could assign readers a heavier processing load than the default SOV order. Sentences with subjects and topic-subjects are in the SOV order, 
which may be faster to process than sentences in the OSV order, including scrambled sentences with surface-initial objects and sentences with surface-initial topic-objects. This prediction is summarized below.

(3) topic-subject-wa, subject-ga < scrambled object-o, topic-object-wa

Moreover, when an object in an OSV sentence is a topic-object, its sentence might be slower to process than a sentence with a scrambled non-topic object. As mentioned earlier, a topic-object may require readers to reanalyze it during processing the sentence because a topic-object might be initially misinterpreted as a topic-subject. This is different from scrambled objects appended with the accusative postposition $o$, which explicitly shows that they are grammatical objects. Thus, sentences with scrambled objects with $o$ might be processed faster than topic-objects with $w a$, as summarized below.

(4) scrambled object $-0<$ topic-object -wa

In sum, four predictions are presented above. The prediction (1) is related to the realization of the referential relationship between anaphors and their antecedents, which is the main objective of this study. The other predictions, (2), (3) and (4), relate to the processing of sentences with subjects, topic-subjects, scrambled objects and topic-objects, irrelevantly to being anaphoric. A self-paced sentence-by-sentence reading experiment was conducted in order to test the prediction (1), but the effects shown in (2), (3) and (4) were also predicted to appear in the results.

\section{Experiment}

\subsection{Participants}

24 Japanese speakers, which consisted of students of the University of South Carolina and residents in South Carolina, North Carolina and Georgia, served as participants in this experiment. They were all native speakers of Japanese, raised in Japan until they were at least 15 years old. The participants consisted of 8 males and 16 females, and their ages ranged from 18 to 52 .

\subsection{Items}

The basic design of the experiment followed that of Gordon, Grosz and Gilliom (1993). A self-paced sentence-by-sentence reading experiment was conducted, in which participants read two-sentence discourse items. ${ }^{2}$ The first sentence included an

\footnotetext{
${ }^{2}$ Gordon et al. (1993) used four-sentence discourse items.
} 
antecedent, which was always prominent as it was a grammatical subject and was firstmentioned in the sentence. The second sentence included a repeated-name anaphor, which was one of the following four types: (i) (non-topic) subject-ga, (ii) topic-subjectwa, (iii) (non-topic) scrambled object-o, or (iv) topic-object-wa. Eight items for each of the four types were prepared, and thus there were 32 experimental items in total. The anaphors and antecedents were always persons' names, and no other proper names were used in the items. The processing times of the second sentences that included anaphors were measured as an indication of how fast participants realized the anaphor-antecedent referential relationship, which tested the prediction (1), or an indication of how fast they processed the sentences independently from the preceding sentences, which tested the predictions (2), (3) and (4).

A yes-no comprehension question followed each discourse item. In order to test the prediction (1), it was of importance that the comprehension questions asked about the antecedents found in the first sentences. According to Gernsbacher $(1989$, p. 107), questions about the clauses that include antecedents that appear before anaphors ensure that readers understand anaphor-antecedent relationship. The author of this study considers that response times for this type of comprehension question would indicate how fast participants successfully realized the referential relationship between anaphors and antecedents. For example, when participants read a discourse such as Taro-ga toshokan-ni itta. Taro-wa yoru osoku made benkyooshita. 'Taro went to the library. Taro studied until late at night.', if they successfully interpret 'Taro' in the second sentence as an anaphor and realize its antecedent (interpreting the discourse like, 'Taro, who went to the library, studied there until late at night'), then they would have little trouble in answering a comprehension question about the antecedent, e.g., 'Did Taro go to a library?' (the answer is Yes). On the other hand, if the participants do not recognize 'Taro' in the second sentence as an anaphor, they have interpreted the second 'Taro' independently from the 'Taro' in the first sentence, building no referential relationship between the two Taros. As a result, they would experience a temporary difficulty in answering the comprehension question that asks about the prior 'Taro'.

This method regarding comprehension questions is a modification of the proberecognition task such as the one in Nakayama's (1990) study. He conducted an experiment with the items like the below (p. 15):

(i) 町を歩いていたおばさんが警察に彼女が泥棒を見たと電話した。 Machi-o aruiteita obasan-ga keisatsu-ni kanojo-gai doroboo-o mita to denwashita.

'A woman who was walking on the street telephoned the police that she saw the thief.' 
(ii) 図書館で勉強している学生が友達に宿題をしておいたと伝えた。 Toshokan-de benkyooshiteiru gakusei-ga tomodachi-ni $\varnothing$ i shukudai-o shiteoita to tsutaeta.

'The student who was studying at the library informed his friend that [null] did homework.'

Antecedents (obasan 'woman' and gakusei 'student') of anaphors (kanojo 'she' and null pronoun) were shown as probe words after participants read the sentences, and the participants were asked whether the probe words appeared in the sentence that they just read. The response times to the probe words were the indication of how fast they realized the anaphor-antecedent referential relationships. Nakayama found that the response times for (i) was slower than those for (ii), indicating that the referential relationships were realized faster with null pronouns than with overt pronouns. The present study could not replicate Nakayama's probe-recognition task: antecedents could not be used as probe words because the antecedents were repeated in the second sentences. Thus, instead of using antecedents as probe words, this study prepared comprehension questions that asked about antecedents. ${ }^{3}$

All items were presented in Japanese texts. The 32 experimental items ( 8 items for four conditions) were given mixed among 68 distractors, and thus there were 100 items in total. Example experimental items for each condition are shown below. (Anaphors in each condition are italicized.)

\section{(i) Subject anaphor}

Two-sentence discourse:

(5) 太郎が図書館に行った。太郎か夜遅くまで勉強した。

Taro-ga toshokan-ni itta. Taro-ga yoru osoku-made benkyoshita.

Taro-NOM library-DIR went Taro-NOM until late at night studied

'Taro went to a library. Taro studied until late at night.'

Comprehension question:

(5Q) 太郎は図書館に行きましたか。

Taro-wa toshokan-ni ikimashita ka.

'Did Taro go to a library?'

\footnotetext{
${ }^{3}$ Gernsbacker (1989) used the antecedents of repeated-name anaphors as probes in her study, which resulted in comparatively faster response times for the repeated-name anaphors. Gernsbacker also suggested that repeated names facilitated faster antecedent-realization compared with pronouns. However, as Gordon et al. (1993, p. 323) highlight, the response times unlikely reflect how fast readers realized the anaphor-antecedent relationship; they may have simply retrieved the anaphors unrelated to the antecedents.
} 


\section{(ii) Topic-subject anaphor}

Two-sentence discourse:

(6) 次郎がレストランで食事をした。次郎はパスタを食べた。 Jiro-ga resutoran-de shokuji-o shita. Jiro-wa pasuta-o tabeta. Jiro-NOM restaurant-LOC meal-ACC did Jiro-TOP pasta-ACC ate 'Jiro ate a meal at a restaurant. Jiro ate pasta.'

Comprehension question:

(6Q) 次郎はレストランで食べましたか。 Jiro-wa resutoran-de tabemashita ka.

'Did Jiro eat at a restaurant?'

\section{(iii) Scrambled object anaphor}

Two-sentence discourse:

(7) 三郎が公園で遊んでいた。三郎をお母さんが迎えに来た。 Saburo-ga kooen-de asonde-ita. Saburo-o okaasan-ga mukaenikita. Saburo-NOM park-LOC was playing Saburo-ACC mother-NOM came to pick up 'Saburo was playing at a park. Mother came to pick up Saburo.'

Comprehension question:

(7Q) 三郎は公園で遊びましたか。 Saburo-wa kooen-de asobimashita ka.

'Did Saburo play at a park?'

\section{(iv) Topic-object anaphor}

Two-sentence discourse:

(8) 四郎がパーティに出席した。四郎はいとこが招待した。 Shiro-ga paatii-ni shusseki-shita. Shiro-wa itoko-ga shootaishita. Shiro-NOM party-DIR attended Shiro-TOP cousin-NOM invited 'Shiro studied at the library. His cousin invited Shiro.'

Comprehension question:

(8Q) 四郎はパーティに出席しましたか。 Shiro-wa paatii-ni shusseki shimasita ka. 'Did Shiro attend a party?' 


\section{Procedure}

The discourse items in the experiment were presented using E-Prime. Participants read two-sentence discourses sentence-by-sentence, in a self-paced reading fashion. The experiment was carried out with each participant viewing the sentences on a computer. During the experiment, the participants first received the welcome message and instructions on the computer screen and proceeded to the practice block by hitting the space bar. The practice block provided four practice questions to familiarize the participants with the sentence-by-sentence reading task. After the participants finished the practice questions, they received the end-of-practice message, and they were allowed to proceed to the actual experiment by hitting the space bar. In the practice block and actual experiment, the first sentence of each experimental discourse appeared after the fixation mark, " + ". After participants read each discourse, a yes-no comprehension question was given, which could be answered by hitting " 1 (yes)" or " 2 (no)". After the comprehension question, the fixation " + " appeared, which was followed by the first sentence of the next discourse. The experimental and distractor discourses were given in random order. A session lasted approximately 20 minutes.

\section{Data Analysis}

The independent variables of the experiment were the anaphors: repeated-name subject- $g a$, repeated-name topic-subject-wa, repeated-name scrambled object-o and repeated-name topic-object-wa. The measured dependent variables were reading times of the second sentences with anaphors and response times to the comprehension questions asking about antecedents. Linear Mixed Effects analyses using SPSS compared these dependent variables between each condition. The data with the participants' wrong answers for the comprehension questions were removed from the analysis, affecting $4.95 \%$ of the data, as the wrong answers indicate that participants did not accurately comprehend the given discourses. When analyzing reading times, an additional $0.26 \%$ of the data with reading times greater than 15,000 milliseconds were removed as outliers. In addition, the reading times that were three standard deviations (SDs) away from each participant's mean were removed, affecting $2.73 \%$ of the data. In total, $7.94 \%$ of the data were removed. Likewise, when analyzing question-response times, $0.39 \%$ of the data with response times greater than 15,000 milliseconds were removed as outliers. Also, response times that were three SDs away from each participant's mean were removed, affecting $3.16 \%$ of the data. In total, $8.5 \%$ of the data were removed. 


\section{Results}

The table and figures below show the mean reading times of the second sentences that included anaphors and response times for the comprehension questions asking about antecedents. ${ }^{4}$

Table 1: Reading Times for Anaphoric Sentences and Response Times for Comprehension Questions

\begin{tabular}{||l|c|c||}
\hline \hline Anaphors & Reading times ms (SD) & Response times ms (SD) \\
\hline \hline Subject-ga & $2358.81(1281.56)$ & $1947.83(903.87)$ \\
\hline Topic-subject-wa & $2306.44(1292.57)$ & $1757.32(772.44)$ \\
\hline Scrambled object-o & $2843.71(1474.71)$ & $2027.02(954.06)$ \\
\hline Topic-object-wa & $3055.87(1549.55)$ & $1789.57(811.28)$ \\
\hline
\end{tabular}

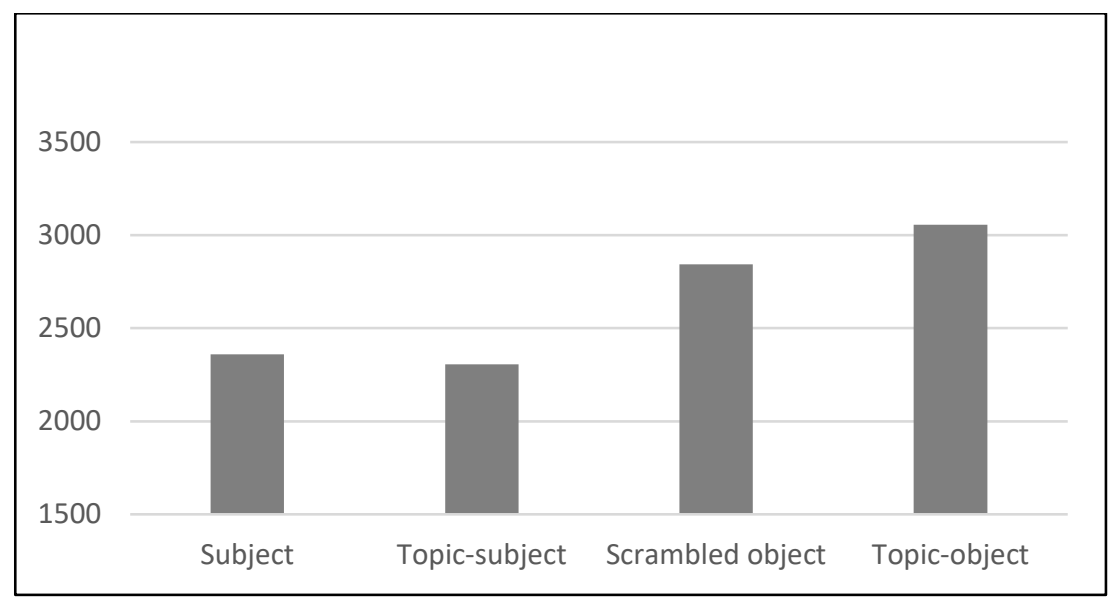

Figure 1: Reading times for anaphoric sentences (second sentences)

\footnotetext{
${ }^{4}$ It was also observed that the accuracy rates for the comprehension questions did not significantly differ between conditions: the accuracy rates were $94 \%$ in subject condition, $95 \%$ for topic-subject condition, $94 \%$ for scrambled object condition, and $97 \%$ for topic-object condition.
} 


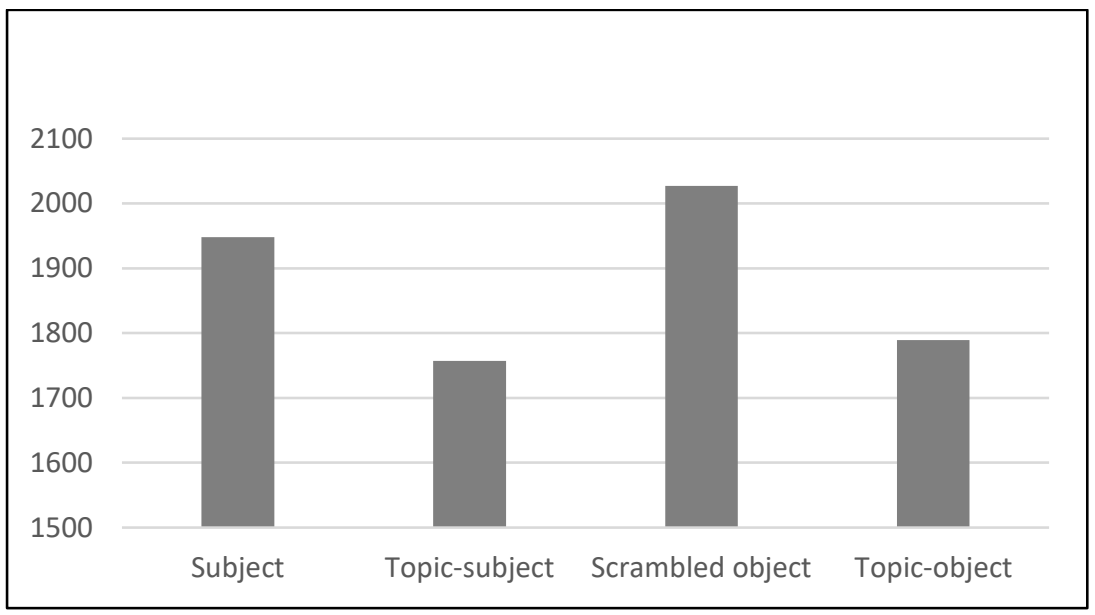

Figure 2: Response times for comprehension questions

The results of the reading times of the second sentences (that included anaphors) showed that sentences with subject-ga anaphors and those with topic-subject-wa anaphors did not significantly differ $[B=52.376, S E=135.878, t=.385, p=.700]$. Also, the reading times for scrambled object- $o$ anaphors and topic-object-wa anaphors did not significantly differ $[B=212.167, S E=161.662, t=1.312, p=.190]$. However, sentences with scrambled object- $O$ anaphors were processed significantly slower than those with subject- $g a$ anaphors $[B=-484.894, S E=147.085, t=-3.297, p=.001]$ and than those with topic-subject-wa anaphors [ $6=-537.270, S E=146.468, t=-3.688, p<$ .001]. Likewise, sentences with topic-object-wa anaphors were processed significantly slower than those with subject-ga anaphors [ $B=-697.060, S E=152.105, t=-4.583, p<$ $.001]$ and than those with topic-subject- $w a$ anaphors $[\theta=-749.436, S E=151.402, t=-$ $4.950, p<.001]$. In short, the reading-time results indicate that SOV sentences with subject-type anaphors (i.e., subject-ga and topic-subject-wa) were processed faster than OSV sentences with object-type anaphors (i.e., scrambled object-o and topicobject-wa).

The results of the response times to the comprehension questions (that asked about antecedents) showed different outcomes. Comprehension questions for the items with topic-subject-wa anaphors were responded to significantly faster than those for the items with subject- $g a$ anaphors $[\theta=190.508, S E=90.030, t=2.116, p=.035]$ and than those for the items with scrambled object- $o$ anaphors $[B=-269.701, S E=$ $92.583, t=-2.931, p=.004]$. Similarly, question-response times for the items with topicobject-wa anaphors were significantly or marginally significantly faster than for those with subject-ga anaphors $[B=158.251, S E=91.176, t=1.736, p=.083]$ and for those with scrambled object- $o$ anaphors $[\theta=-237.443, S E=93.575, t=-2.537, p=.012]$. There was no significant difference between the response times for the items with topicsubject- $w a$ anaphors and topic-object- $w a$ anaphors $[B=-32.257, S E=83.540, t=-.386$, $p=.700]$. Also, there was no significant difference between the response times for the 
items with subject-ga anaphors and scrambled object-o anaphors $[B=-79.193, S E=$ 100.091, $t=-.791, p=.429]$. In short, question-response times were faster for the discourse items with topic-type anaphors (i.e., topic-subject-wa and topic-object-wa) than for items with non-topic-type anaphors (i.e., subject-ga and scrambled object-o).

\section{Discussion}

The results of the reading times of the second sentences with anaphors can be attributable to word order, as indicated by the prediction (3). The sentences with subject anaphors and topic-subject anaphors are in the default SOV order, and those with scrambled object anaphors and topic-object anaphors are in the OSV order. The results showed that SOV sentences were faster to process than OSV sentences. Also, the reading-time results for topic-subject anaphors and topic-object anaphors can be attributable to the prediction (2). Readers might have misinterpreted topic-objects as topic-subjects, and later they had to reanalyze the interpretation. Thus, sentences with topic-objects were processed more slowly than those with topic-subjects.

The prediction (4), scrambled objects should be processed faster than topicobjects, did not appear in this experiment. Scrambled objects with the accusative postposition $o$ should have been immediately realized as objects while topic-objects with wa should have been initially misinterpreted as topic-subjects. Nevertheless, they were read at indifferent speeds. This result can mean that the reanalysis of topicobjects does not require processing cost enough to significantly slow down its overall processing. If this possibility is true, there should be no reading-time difference between topic-subjects and topic-objects as well, and thus the prediction (2) should not account for the overall results for reading times. Thus, the prediction (3), SOV vs. OSV, solely accounts for the reading time results.

The prediction (1) that suggests the advantage of topic anaphors for realizing anaphor-antecedent relationship did not appear in the reading-time results. This outcome implies that the reading-time differences only reflect the word-order effects, which may have overridden the possible effect predicted by (1). On the other hand, the prediction (1) was supported by the results of response times to comprehension questions. The question-response times for the items with topic-type anaphors (i.e., topic-subject and topic-object) were faster than for non-topic-type anaphors (i.e., subject and scrambled object) at significant or marginally significant levels. The results indicate that, when participants read the second sentences with topic-type anaphors, the topic postposition wa signaled to them that the topic entities overlapped the antecedent entities, resulting in immediate realization of their referential relationship. In other words, the participants possibly interpreted the given two sentences as one continuous discourse that described one person whose name appeared in the 
discourse. Thus, they quickly responded when they were asked about the antecedents, the person, in the first sentences.

In contrast, the slower question-response times for the items with non-topic-type anaphors may indicate that the readers processed the second sentences with the anaphors independently and discontinuously from the first sentences with antecedents. Readers seemed to have shifted their attention away from the first sentence when they processed the second sentence. In other words, processing nontopic-type anaphors initially did not trigger realization of the referential relationship between the anaphors and antecedents. ${ }^{5}$ The participants were likely reminded of the antecedents only when comprehension questions asked about them, resulting in slower responses.

\section{Limitations}

A possible limitation of this study is that the experimental items were all different, not given in the Latin-Square style. Should the same discourse items be used with only different anaphors, the results would have been more plausible. Another limitation could be found in the familiarity of the persons' names that were used as anaphors and as antecedents in experimental items. Common names could be processed faster than relative rare names. There could have been a familiarity-check survey with native Japanese speakers, and only common names should have been used. Future research for the same objective as the one for the present study can be conducted with the modifications regarding the above problematic factors in experimental design.

\section{Conclusion}

This study investigated referential resolution in Japanese using four different types of repeated-name anaphors. The results showed that word order affects sentenceprocessing and that, more importantly, topic-hood of anaphors (indicated by the topic postposition $w a$ ) contributes to building referential relationships between anaphors and antecedents. The fact that topic anaphors and non-topic anaphors elicited different outcomes provide an implication for future studies that examine referential expressions. That is, while most existing studies focus on anaphors' forms such as pronouns vs. repeated names, morphological markings such as wa or ga in Japanese should be also considered, which will contribute to cross-language understandings of

\footnotetext{
${ }^{5}$ One of the participants gave a comment to the author after the experiment: 'I experienced a wired feeling that the images that I created from the sentences did not quickly connected'. This comment might express that the images from non-topic anaphors without wa were not quickly connected to the images from antecedents.
} 
referential resolution. The present study is one such study that examines the effects of morphological markings. Similar research in other morpheme-marking languages could be conducted to verify the replicability of this study. Such follow up studies may find it universal that morphological topic-marking functions to helps readers realize referential relationships between anaphors and antecedents.

\section{References}

Ariel, M. (1990). Accessing noun-phrase antecedents. New York: Routledge.

Chafe, W. (1987). Cognitive constraints on information flow. In R. Tomlin (Ed.), Coherence and grounding (pp. 21-52) Amserdam: John Benjamins.

Gernsbacher, M. A. (1989). Mechanisms that improve referential access. Cognition, 32(2), 99156. Retrieved from: https://www.ncbi.nlm.nih.gov/pmc/articles/PMC4467536/

Gordon, P. C., Grosz, B. J. \& Gilliom, L. A. (1993). Pronouns, names, and the centering of attention in discourse. Cognitive Science, 17, 311-347.

Gordon, P. C., \& Hendrick, R. (1998). The representation and processing of coreference in discourse. Cognitive Science, 22, 389-424.

Gundel, J. K., Hedberg, N., \& Zacharski, R. (1993). Cognitive status and the form of referring expressions in discourse. Language, 69, 274-307.

Halliday, M. A. K. (1967). Notes on transitivity and theme in English. Journal of Linguistics, 19, 377-417.

Haviland, S. E., \& Clark, H. H. (1974). What's new? Acquiring new information as a process in comprehension. Journal of Verbal Learning and Verbal Behavior, 13, 512-521.

Kuno, S. (1973). The structure of Japanese language. Cambridge, MA: MIT Press.

Martin, S. (1975). A reference grammar of Japanese. New Haven, CT: Yale University Press.

Nakayama, M. (1990). Accessibility to the antecedents in Japanese sentence comprehension. Unpublished manuscript.

Nishimura, M. (1989). The topic-comment construction in Japanese-English code-switching. World Englishes, 8, 365-377.

Prince, E. F. (1978). On the function of existential presupposition in discourse. Papers from the Fourteenth Regional Meeting, Chicago, IL: Chicago Linguistics Society. 